\title{
UNIVERSITYOF
}

FORWARD

THINKING

WESTMINSTER用

WestminsterResearch

http://www.westminster.ac.uk/westminsterresearch

Macro environmental analysis of the electric vehicle battery

second use market

Reinhardt, R., Domingo, S.G., García, B.A. and Christodoulou, I.

This is a copy of the author's accepted version of a paper subsequently published in the proceedings of the 14th International Conference on the European Energy Market (EEM), Dresden, Germany, 6th to 9th June 2017, IEEE.

It is available online at:

https://dx.doi.org/10.1109/EEM.2017.7982031

(C) 2017 IEEE . Personal use of this material is permitted. Permission from IEEE must be obtained for all other uses, in any current or future media, including reprinting/republishing this material for advertising or promotional purposes, creating new collective works, for resale or redistribution to servers or lists, or reuse of any copyrighted component of this work in other works.

The WestminsterResearch online digital archive at the University of Westminster aims to make the research output of the University available to a wider audience. Copyright and Moral Rights remain with the authors and/or copyright owners.

Whilst further distribution of specific materials from within this archive is forbidden, you may freely distribute the URL of WestminsterResearch: ((http://westminsterresearch.wmin.ac.uk/)).

In case of abuse or copyright appearing without permission e-mail repository@westminster.ac.uk 


\section{Macro environmental analysis of the electric vehicle battery second use market}

\author{
Robert Reinhardt \\ Santiago Gassó Domingo \\ Beatriz Amante García \\ Department of Project and Construction Engineering \\ Universitat Politècnica de Catalunya \\ Barcelona, Spain
}

\author{
Ioannis Christodoulou \\ Department of Marketing and Business Strategy \\ University of Westminster \\ London, United Kingdom
}

\begin{abstract}
The end-of-life (EOL) strategy of repurposing degraded electric vehicle (EV) batteries in second use applications holds the potential to reduce first-cost obstacles of EVs. With a prospective EV market uptake, increasing numbers of retired batteries will be available soon for battery second use (B2U). But this emerging secondary market remains unclear from a business model perspective. This paper evaluated the evolving B2U market from a macro environmental perspective to comprehend key opportunities and threats in the future.
\end{abstract}

Index Terms-Battery Second Use; Macro-Environment; Business Strategy; Business Models; Electric Vehicle

\section{INTRODUCTION}

The global automotive industry appears to be on the tip of a revolution towards electric mobility, especially with regards to electric vehicles (EVs), which use chemical energy stored in rechargeable battery packs. However, today a wider market uptake of EVs is mainly hindered by the high costs of commercially installed battery packs [1]. Furthermore there exists the criticism that EVs are seen as 'green washing' as most vehicles are still charged with non-renewable electricity such as from coal and gas, which transfers emissions from the transport to the energy sector [2]. Simultaneously, there is an increasing concern over the quality and continuity of supply and a trend towards renewable energy production and decentralized generation such as photovoltaic and wind turbines, which all stress the importance for adequate electrical storage capacities in upcoming years [3].

EVs have recently attracted increased attention from the electricity markets as they can provide valuable services to the energy markets by offering grid services such as peak load shifting and integrating renewable energies [4], [5]. But, a prospective market uptake of EVs also poses threats and challenges to the grid as there will be additional electricity sales for utilities and increased demands for charging infrastructures and related services. The appearance of energy storage technologies represents a viable solution to these problems by providing services such as load levelling and backup power. However, the integration and storage of intermittent renewables is still challenging due to the lack of cost-effective large-scale energy storage systems [6], [7].

Apart from these technological challenges that must be overcome, there are issues around end-of-life (EOL) disposal mechanisms for automotive manufacturers. It will be several years before the first mass-market generation of degraded EV batteries will start to retire. However, current recycling frameworks for automotive lithium-ion batteries do not contribute to waste and resource exploitation issues and are motivated by economic revenues while disregarding that recapturing value from these batteries in alternative secondary applications could potentially be an engine for the transition towards a more sustainable transport sector [8], [9]. In this respect, repurposing retired $\mathrm{EV}$ batteries for secondary applications may provide a cost-effective solution to address these challenges. EV batteries are considered not useful for traction purposes and have degraded after a service life of about 6-8 years [10]. However, as these batteries still remain a state of health of around $70 \%-80 \%$, one feasible solution to reuse these batteries more efficiently while decreasing overall battery lifecycle costs, is to repurpose them for less demanding battery second use (B2U) applications such as renewable energy storage and back-up [11]-[14].

The global B2U market is predicted to grow from $\$ 16$ million in 2014 to $\$ 3$ billion in 2035 [15]. Many studies [10][13], [16]-[21] have evaluated the technical and economic feasibilities of B2U whereby no major technical barriers for wider adoption on larger scales were found. With regards to the economic features, it is suggested that using degraded EV batteries for stationary storage applications such as grid support or power backup, represents an economic feasible option as it extends total battery life time value and offers a cost effective solution to presently cost expensive storage systems [8], [18]-[21]. This means that degraded EV batteries may disrupt the current shape of the automotive and energy markets as they represent much cheaper electricity storage from renewables than is available today as well as 
that EV manufacturers can charge less for their vehicles if their batteries prove to have value in a second life. Thus, secondary markets for discarded EV batteries are emerging whereby the current preferred method of recycling discarded batteries may be diminished and new innovative business models will arise that have yet to be quantified.

The paper is organised as follows: Section II describes the research approach, Section III discusses opportunities and threats in the emerging B2U market from a macro environmental perspective, followed by conclusions and future research directions in Section IV.

\section{RESEARCH APPROACH}

This research aims to contribute to the scientific literature on business strategy in the case of EV B2U as very few authors [1] to date have studied business model perspectives in the case of B2U and thus a research gap has been identified. Sustainable technologies such as B2U, which have the specific feature to decrease environmental degradation, challenge current dominant business practices that are heavily dependent on the use of fossil fuels such as the automotive industry [22]. The emerging market for degraded EV batteries is therefore in need of business models that create economic value and address barriers for a further market penetration based on a process of learning, experimentation and adaption [23]. Finding the right business models at an early stage in emerging industries such as the B2U market is however still very rare [24].

Thus, novel business strategies around B2U have emerged such as the appearance of the start-up company Better Place that introduced the concept of battery swapping stations, which replace degraded EV batteries with a fully charged battery of the same type in less than 5 minutes [25]. But, the company had to file for bankruptcy in 2012, losing $\$ 812$ million, mainly caused by the high initial investments needed to set up their business infrastructures coupled with mismanagement issues such as the overestimated market penetration in their pilot study countries. However, the case of Better Place demonstrates that current prevailing business models and strategies in the EV B2U industry might be considered under new approaches from product-based towards fully service driven [26].

Due to the complex and exploratory nature of the research context, this study makes use of the qualitative methodological case study approach, which aims to study things in their natural settings by interpreting phenomena in terms of the meaning people bring to them mainly expressed through non-numerical beliefs, opinions, ideas and attitudes [27]. The approach of the comparative case study approach is applied, where the focus is within and across cases and hence the evidence and overall study is therefore regarded as more robust [28]. As the objective of this study is to evaluate similar or contrasting trends in the arising global B2U industry, the three representative case study regions of Europe, Asia, and United States of America (USA) have been chosen as this is where most progress has recently been made with regards to $\mathrm{B} 2 \mathrm{U}$ pilot projects.
The data for the case studies were collected using secondary data sources including scientific and academic journals, governmental and non-governmental organizational publications, and press releases. To analyse gathered data from the selected case study regions, this study makes use of the macro environmental analysis technique of the Political, Economic, Social, Technological, Environmental, and Legal (PESTEL) framework as the selected cases contain some or all the framework's factors (Fig. 1).

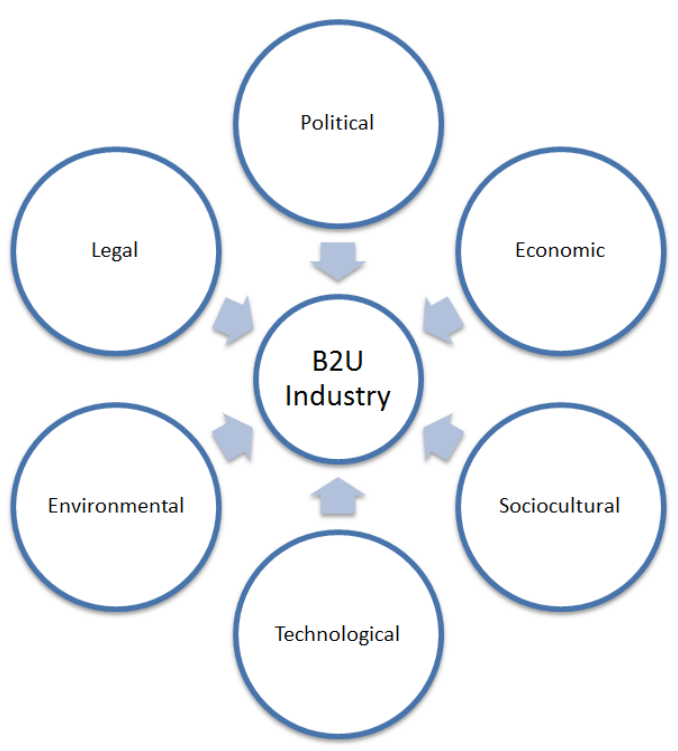

Figure 1. The PESTEL framework

The application of this strategic management tool allows comprehending the 'big picture' trough an examination of a variety of external factors that may have an impact either now or in the future on the benefits, issues and problems around the global B2U market and it provides a comprehensive list of potential success or failure of particular strategies [29]. Due to the complexity of the research context and the possibility of being overwhelmed by a multitude of details, only those key drivers for change are identified that are most important with regards to the B2U market in the case study regions. These external drivers are continuously given the highest priority and their implications are classified into external opportunities and threats that affect the global B2U either now or in the future [30]. Lastly, commercial B2U projects are still very rare today, because of limited EV market share and economic uncertainties of B2U projects. Thus, there is the issue of limited data availability and generalization of proposed research findings. However, in comparing or replicating developments in the emerging B2U market with the help of the selected case study regions with each other in a systematic way, it can be explored and concluded which recommendations may or may not be feasible soon. 


\section{RESULTS AND DISCUSSION}

With prospective increased global EV market share, a growing number of retired EV batteries will become available for the emerging B2U market. Therefore, the global automotive sector has attracted a growing interest from the energy markets in recent years and led to a variety of leading EV manufactures evaluating how much value their batteries have in a second life through the development of pilot projects, as presented in Table I.

TABLE I. EXAMPLES OF B2U PILOT PROJECTS

\begin{tabular}{|c|c|c|}
\hline Joint Ventures & Description & Location \\
\hline $\begin{array}{l}\text { Daimler } \\
\text { GETEC/The } \\
\text { Mobility House } \\
\text { Remondis/EnBW }\end{array}$ & $\begin{array}{l}\text { Battery storage unit with a total } \\
\text { capacity of } 13 \text { MWh using degraded } \\
\text { EV batteries from Daimler EV } \\
\text { models }\end{array}$ & $\begin{array}{l}\text { Luenen, } \\
\text { Germany }\end{array}$ \\
\hline BMW/PG\&E & $\begin{array}{l}\text { 18-month pilot project to } \\
\text { demonstrate EV smart charging and } \\
\text { optimization grid efficiency with } \\
\text { participation of } 100 \mathrm{BMW} \mathrm{i3} \\
\text { owners }\end{array}$ & $\begin{array}{l}\text { San } \\
\text { Francisco, } \\
\text { USA }\end{array}$ \\
\hline $\begin{array}{l}\text { Nissan } \\
\text { Sumitomo (4R } \\
\text { Energy)/Green } \\
\text { Charge Networks }\end{array}$ & $\begin{array}{l}\text { System }(600 \mathrm{kWh} / 400 \mathrm{kWh}): 16 \\
\text { Nissan Leaf LIBs regulate energy } \\
\text { from a solar plant }\end{array}$ & $\begin{array}{l}\text { Osaka, } \\
\text { Japan }\end{array}$ \\
\hline $\begin{array}{l}\text { BMW/Vattenfall/ } \\
\text { Bosch }\end{array}$ & $\begin{array}{l}2,600 \text { battery modules from } 100 \\
\text { electric cars, and provides } 2 \mathrm{MW} \text { of } \\
\text { output and } 2.8 \mathrm{MWh} \text { of capacity }\end{array}$ & $\begin{array}{l}\text { Hamburg, } \\
\text { Germany }\end{array}$ \\
\hline $\begin{array}{l}\text { Renault/Connected } \\
\text { Energy Ltd }\end{array}$ & $\begin{array}{l}\text { "E-STOR": on-grid providing } \\
\text { energy storage that prevents power } \\
\text { grid overload and balances supply } \\
\text { and demand }\end{array}$ & $\begin{array}{l}\text { United } \\
\text { Kingdom, } \\
\text { Europe }\end{array}$ \\
\hline $\begin{array}{l}\text { Mitsubishi/PSA } \\
\text { EDF/Forsee } \\
\text { Power/ } \\
\text { MMC }\end{array}$ & $\begin{array}{l}\text { Bi-directional battery energy } \\
\text { consumption optimization from } \\
\text { retired batteries }\end{array}$ & $\begin{array}{l}\text { Paris, } \\
\text { France }\end{array}$ \\
\hline $\begin{array}{l}\text { General Motors/ } \\
\text { ABB }\end{array}$ & $\begin{array}{l}5 \text { Chevrolet Volt LIBs, } 74 \mathrm{~kW} \text { solar } \\
\text { array \& two } 2 \mathrm{~kW} \text { wind turbines to } \\
\text { power a GM office building site }\end{array}$ & $\begin{array}{l}\text { Michigan, } \\
\text { USA }\end{array}$ \\
\hline
\end{tabular}

It is evident that there is a growing investment, experimentation, and interest in $\mathrm{B} 2 \mathrm{U}$, and indicating the creation of a secondary market for retired EV batteries and hence new market opportunities. Nevertheless, the economic value of degraded EV batteries in this second life has yet to be quantified and it can be concluded that most developments are speculative at this point.

\section{A. The Macro Environment}

A good starting point to comprehend this evolving industry from a business model perspective is to evaluate the macro environment. The findings of the PESTEL analysis in the global B2U market have been prioritized and classified into the external factors of opportunities and threats, as shown in Fig. 2.

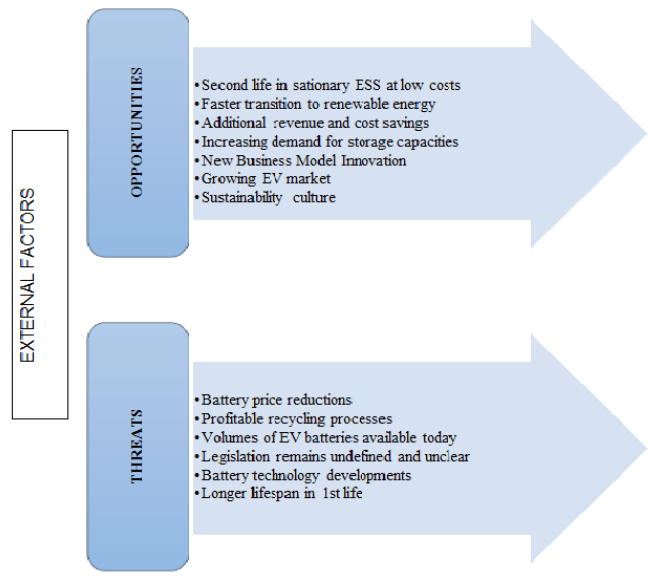

Figure 2. Opportunities and threats of battery second use industry

\section{1) Opportunities}

The appearance of B2U holds the potential to be a more viable EOL solution for degraded $\mathrm{EV}$ batteries than recycling. Thus, B2U can address key issues on side of EV manufacturers as the total lifetime value of a battery can be extended by increasing its economic revenue through second use alternative applications, the initial cost of the battery can be decreased as linked energy and material investments compensate initial battery cost and the recycling phase is postponed where by raw materials may be recirculated into new battery production cycles (Fig. 3). Essentially, B2U can help improve first cost hurdles of traction batteries and EVs respectively through implementing the principles of the circular economy approach that are to keep products and materials in a closed-loop life cycle by preserving natural capital, optimising resource yields and minimising system risks.

\begin{tabular}{|c|c|c|}
\hline First Life & Second Life & Recycle \\
\hline $\begin{array}{l}\text { - In-use phase } \\
\text { 8-10 years } \\
\text { - Battery testing } \\
\text { - Battery } \\
\text { Refurbishment }\end{array}$ & $\begin{array}{l}\text { - Affordable at } \\
\text { low costs in } \\
\text { ESS } \\
\text { - Reduced } \\
\text { totalcost of } \\
\text { Ownership for } \\
\text { EVs } \\
\text { - Increase } \\
\text { reputation as } \\
\text { "zero } \\
\text { emission" } \\
\text { vehicles } \\
\text { - Less demand } \\
\text { for new } \\
\text { batteries and } \\
\text { reources }\end{array}$ & $\begin{array}{l}\text { - Reduced } \\
\text { demand and } \\
\text { consumption } \\
\text { of resources } \\
\text { - Recirculation } \\
\text { of recovered } \\
\text { raw materials } \\
\text { into battery } \\
\text { production } \\
\text { cycle }\end{array}$ \\
\hline
\end{tabular}

Figure 3. Battery second use process 
A recent study [31], using EV sales forecasts as set out by [32] and considering average battery sizes between 24 kilowatt-hours $(\mathrm{kWh})-64 \mathrm{kWh}$ and secondary life rate of $80 \%$ after a 7 year EV in-use phase, forecasts that global EV cumulative sales will reach 6.7 million by 2020 and 88 million by 2030 ; at the same time cumulative installed capacity of secondary batteries are predicted to reach 230 Gigawatt hours (GWh) in 2025 and an increase by four times to $1000 \mathrm{GWh}$ in 2030 [31]. Previous studies [10], [33] estimate further 10 years of battery lifetime in B2U applications (after automotive service) with initial $80 \%$ capacity and an average decrease of $7.5 \%$ by year in their available capacity, reaching $50 \%$ at the end of their stationary life before undergoing recycling processes. Hence, B2U may generate additional revenues and decrease total cost of ownership and environmental impact of EVs.

There are two major business opportunities for degraded $\mathrm{EV}$ batteries, which are to create groups of battery packs for larger commercial/industrial applications $(25 \mathrm{kWh}-50$ Megawatt hours) or for smaller applications such as residential related or commercial offices and buildings (3-4 $\mathrm{kWh}$ ) [34]. From an economic point of view and given that the B2U industry is still in its infancy stage, it is less risky to invest in many small applications such as residential energy storage. This economic potential in smaller applications is reflected when looking at the B2U business landscape. Most recently, Japanese car manufacturer Nissan has started preorders in Germany, UK and Norway with its residential energy storage unit 'Xstorage', which is built of 12 retired $\mathrm{EV}$ batteries, and connected to the grid or renewable generators, offering its customers time-of-use pricing and back-up power [35]. German automaker BMW also plans to enter the residential energy storage market soon, recently announcing to use retired i3 batteries as a plug-and-play storage application with capacity of 22 or $33 \mathrm{kWh}$ [36].

$\mathrm{B} 2 \mathrm{U}$ may has the potential to deliver the same purpose as newly fabricated batteries in energy storage applications but at substantially lower costs while at the same time accelerating the transition towards increased integration of intermittent renewable energy. A study by [17], using different assumptions on battery degradation, repurposing costs and competitive technologies, estimated that $\mathrm{B} 2 \mathrm{U}$ is economically viable for commercial and industrial end-users with payback periods of 7-10 years and a selling price of a repurposed EV batteries between $\$ 38 / \mathrm{kWh}-\$ 132 / \mathrm{kWh}$. But, these estimates may not include all possible energy storage market opportunities of $\mathrm{B} 2 \mathrm{U}$ as well as that prospective cheaper and more technological advanced battery technologies may drive down the residual value of retired EV batteries.

From a business model perspective, within the emerging B2U and interrelated EV industry a mature business model is far off as the core elements of the traditional business model are still unclear such as to the value proposition, target customer segments and roles within the value network. Hence, business model innovation through the appearance of the sustainable technology B2U may create new sources of value and reconfigures the network of stakeholders involved in creating while having a positive impact on the environment and society [37], [38]. This will lead to firms no longer acting autonomously but it is likely that in the future, specialised companies will repurpose and distribute retired EV batteries in close collaboration with automotive original equipment manufacturers [39].

\section{2) Threats}

In theory everyone can agree, that B2U in energy storage applications can increase total battery life time, address resource consumption and waste management issues and open new market opportunities. However, the actual feasibility of this evolving market is purely profit driven and its success will depend on the following factors.

Primarily, there is a lack of global and fiscal legislations and government support. As the economics of the B2U market is directly linked to a prospective EV market uptake, increasing efforts of global policies and fiscal subsidies to stimulate the market penetration of EVs are urgently needed. Recently, one study [40] demonstrated that funded public policies in the EV key markets in USA, EU and Asia have led to faster adoption rates. However, with regards to B2U there exists no single targeted legislation. Both, automotive and energy binding legislations should achieve a harmonized policy framework that allows for flexibility options such as storing energy from degraded EV batteries in B2U projects. Furthermore, policy makers shall clarify liability options for EOL batteries through the implementation of already established concepts such as extended producer responsibility. Financial incentives for B2U applications and additional incentives for pilot projects can further accelerate a transition towards a more sustainable transport system.

Besides this, there is the threat of price reductions of newly fabricated EV lithium-ion batteries. A study by [41] analysed 80 different cost estimates between 2007-2014 in a systematic way and concluded that battery prices fell by $14 \%$ annually from more than $\$ 1000 / \mathrm{kWh}$ in 2007 to $\$ 410 / \mathrm{kWh}$ in 2014, while battery packs from leading EV manufacturers are predicted to be even lower, at around $\$ 300 / \mathrm{kWh}$. The authors suggest in a further study [42] that it is plausible that battery prices will continue to decline to around $\$ 200-250 / \mathrm{kWh}$ in 2020 and $\$ 150 / \mathrm{kWh}$ in 2025 . Hence, there might be a threat of whether B2U can sustain itself as a profitable and competitive solution.

As EV batteries have their own individual state of health depending on their previous exposure and treatment in their first-life, costly manual disassembly processes are currently the norm as each battery must be cleaned, inspected and replaced to reach like new condition [43]. Therefore, a standard testing procedure is urgently needed so that degraded batteries can be safely used in B2U applications. Presently, the independent safety standard organization UL is developing a safety standard procedure (UL 1974) for retired EV batteries through e.g. tracking rates of electrical charge and discharge [44]. It is likely that the cost of doing business will be decreased once the UL 1974 has been published, but currently it remains a difficult challenge to study all the 
differences of each retired battery including a consideration of their specific B2U application. According to a recent study [45] recycling degraded EV batteries represents a more costeffective option to create most from existing materials of these batteries compared to B2U; the study concludes that an oversized B2U $11.2 \mathrm{kWh}$ residential energy storage system will cost $\$ 4,600$ compared with $\$ 6,000$ for a new $7 \mathrm{KWh}$ system but factored in round-trip efficiency and cycle life hence representing a more feasible option. With ongoing price reductions but also with new battery technologies entering the EV market soon, prices of new energy storage systems will further drop and represent a strong competition to the B2U market. With regards to the B2U industry in the US, Tesla is in favour for recycling batteries at their Gigafactory in Nevada, claiming that recycling processes will use $100 \%$ clean renewable electricity, recover $100 \%$ of the battery's lithium and achieve drastic battery cost reductions as most of the expensive battery materials can be recovered and recirculated into new production cycles. Looking at the European B2U landscape, EV market leaders such as Daimler and BMW appear to fully believe in the B2U potential through their ongoing pilot projects and investments.

Comprehending these factors, the emerging B2U industry is facing many technological, market and policy threats. It must be underlined that a prospective B2U market is not only dependent on the battery sector but also to automotive industry itself as an EV market uptake and their competitiveness to gasoline cars is key for degraded EV batteries to increasingly become available for B2U.

\section{CONCLUSIONS AND FUTURE RESEARCH}

This paper highlights that the B2U market landscape remains mysterious from a business model perspective, because it will still be several years before the first massmarket generation of EV batteries starts to retire. Further, B2U projects are mostly still in demonstration stages and therefore no companies have yet specialized in the field on a large scale. This also leads to uncertainty with regards to a future market potential as the optimal business model needs to be quantified as no B2U market exists just yet.

This paper further emphasizes that new relationships between the automotive and energy sectors are forming where it is likely that in the future inter-industry collaboration as part of business model innovation approaches is key to create additional sources of value.

Hence, future research shall focus on multi-stakeholder perspectives and how companies would interact to efficiently use degraded EV batteries in B2U applications. Due to the issue of limited data availability, future research shall also evaluate those micro factors that will affect companies participating in the B2U market and how business model innovation can serve as a trigger for achieving sustainable competitive advantage as a strong research gap from a business model perspective remains for both industry and academics.

\section{ACKNOWLEDGMENT}

The authors gratefully acknowledge the scholarship FI-DGR 2016 of the Agency for Management of University and Research Grants for giving the opportunity to investigate in such an interesting and innovative field.

\section{REFERENCES}

[1] N. Jiao and S. Evans, 'Business Models for Sustainability: The Case of Second-life Electric Vehicle Batteries', Procedia CIRP, vol. 40, pp. 250-255, 2016.

[2] F. Mariasiu, 'Energy Sources Management and Future Automotive Technologies: Environmental Impact', Int. J. Energy Econ. Policy, vol. 2, no. 4, pp. 342-347, 2012.

[3] S. Küfeoğlu and M. Lehtonen, 'A Review on the Theory of Electric Power Reliability Worth', in 13th International Conference on the European Energy Market (EEM), 2016, pp. 1-6.

[4] S. B. Peterson, J. F. Whitacre, and J. Apt, 'The economics of using plug-in hybrid electric vehicle battery packs for grid storage', $J$. Power Sources, vol. 195, no. 8, pp. 2377-2384, 2010.

[5] J. Y. Yong, V. K. Ramachandaramurthy, K. M. Tan, and N. Mithulananthan, 'A review on the state-of-the-art technologies of electric vehicle, its impacts and prospects', Renew. Sustain. Energy Rev., vol. 49, pp. 365-385, 2015.

[6] C. Heymans, S. B. Walker, S. B. Young, and M. Fowler, 'Economic analysis of second use electric vehicle batteries for residential energy storage and load-levelling', Energy Policy, vol. 71, pp. 22-30, 2014.

[7] E. N. Elkind, 'Reuse and Repower: How to Save Money and Clean the Grid with Second-Life Electric Vehicle Batteries', 2014.

[8] L. Gaines, J. Sullivan, A. Burnham, and I. Belharouak, 'Life-Cycle Analysis for Lithium-Ion Battery Production and Recycling', 90th Annual Meeting of the Transportation Research Board. Washington: Argonne National Laboratory, 2011.

[9] M. O. Ramoni and H. C. Zhang, 'End-of-life (EOL) issues and options for electric vehicle batteries', Clean Technol. Environ. Policy, vol. 15, no. 6, pp. 881-891, 2013.

[10] L. Ahmadi, M. Fowler, S. B. Young, R. A. Fraser, B. Gaffney, and S. B. Walker, 'Energy efficiency of Li-ion battery packs re-used in stationary power applications', Sustain. Energy Technol. Assessments, vol. 8, no. November, pp. 9-17, 2014.

[11] E. Cready, J. Lippert, J. Pihl, I. Weinstock, and P. Symons, 'Technical and Economic Feasibility of Applying Used EV Batteries in Stationary Applications', Alburquerque, NM (US), 2003.

[12] P. Wolfs, "An economic assessment of "second use" lithium-ion batteries for grid support', in Universities Power Engineering Conference (AUPEC), 2010 20th Australasian, 2010, pp. 1-6.

[13] J. Neubauer and A. Pesaran, 'The ability of battery second use strategies to impact plug-in electric vehicle prices and serve utility energy storage applications', J. Power Sources, vol. 196, no. 23, pp. 10351-10358, 2011.

[14] D. Beverungen, S. Bräuer, F. Plenter, B. Klör, and M. Monhof, 'Ensembles of context and form for repurposing electric vehicle batteries: an exploratory study: Completed Research Paper', Comput. Sci. - Res. Dev., pp. 1-15, 2016.

[15] S. Jaffe and K. Adamson, 'Second-Life Batteries $\square$ : From PEVs to Stationary Applications', 2014. [Online]. Available: http://www.navigantresearch.com/wpcontent/uploads/2014/01/RB-SLB-14-Executive-Summary.pdf. 
[16] V. V Viswanathan and M. Kintner-Meyer, 'Second use of transportation batteries: Maximizing the value of batteries for transportation and grid services', IEEE Trans. Veh. Technol., vol. 60, no. 7, pp. 2963-2970, 2011.

[17] J. S. Neubauer, A. Pesaran, B. Williams, M. Ferry, and J. Eyer, 'A techno-economic analysis of PEV battery second use: Repurposedbattery selling price and commercial and industrial end-user value', SAE Tech. Pap., 2012.

[18] L. Gaines and R. Cuenca, 'Costs of Lithium-Ion Batteries for Vehicles', Energy, vol. 48, no. 3, p. 73, 2000.

[19] B. Williams and T. Lipman, 'Strategy for Overcoming Cost Hurdles of Plug-In-Hybrid Battery in California', Transp. Res. Rec., vol. 2191, no. 1, pp. 59-66, 2010.

[20] S. Beer, T. Gómez, D. Dallinger, I. Momber, C. Marnay, M. Stadler, and J. Lai, 'An economic analysis of used electric vehicle batteries integrated into commercial building microgrids', IEEE Trans. Smart Grid, vol. 3, no. 1, pp. 517-525, 2012.

[21] W.-C. Lih, J.-H. Yen, F.-H. Shieh, and Y.-M. Liao, 'Second-use Applications of Lithium-ion Batteries Retired from Electric Vehicles: Challenges, Repurposing Process, Cost Analysis and Optimal Business Model', Int. J. Adv. Comput. Technol., vol. 4, no. 22, pp. 518-527, 2012.

[22] F. Kley, C. Lerch, and D. Dallinger, 'New business models for electric cars-A holistic approach', Energy Policy, vol. 39, no. 6, pp. 3392-3403, 2011.

[23] R. Bohnsack, J. Pinkse, and A. Kolk, 'Business models for sustainable technologies: Exploring business model evolution in the case of electric vehicles', Res. Policy, vol. 43, no. 2, pp. 284 300, 2014.

[24] D. J. Teece, 'Business models, business strategy and innovation', Long Range Plann., vol. 43, no. 2-3, pp. 172-194, 2010.

[25] Y. Zheng, Z. Y. Dong, Y. Xu, K. Meng, J. H. Zhao, and J. Qiu, 'Electric vehicle battery charging/swap stations in distribution systems: Comparison study and optimal planning', IEEE Trans. Power Syst., vol. 29, no. 1, pp. 221-229, 2014.

[26] T. Budde Christensen, P. Wells, and L. Cipcigan, 'Can innovative business models overcome resistance to electric vehicles? Better Place and battery electric cars in Denmark', Energy Policy, vol. 48, pp. 498-505, 2012.

[27] K. F. Punch, Introduction to social research - quantitative \& qualitative approaches, 3rd ed. London: SAGE, 2014.

[28] R. K. Yin, Case Study Research: Design and Methods. London: SAGE, 1994.

[29] I. Worthington and C. Britton, The Business Environment. London: Financial Times Prentice Hall, 2003.

[30] G. Johnson, K. Scholes, and R. Whittington, Exploring Corporate Strategy. London: Financial Times Prentice Hall, 2008.

[31] G. Reid and J. Julve, 'Second Life-Batteries As Flexible Storage For Renewables Energies', 2016. [Online]. Available: http://www.bee-

ev.de/fileadmin/Publikationen/Studien/201604_Second_Life-

Batterien_als_flexible_Speicher.pdf.

[32] Bloomberg, 'Here's How Electric Cars Will Cause the Next Oil Crisis', 2016.2 [Online]. Available: https://www.bloomberg.com/features/2016-ev-oil-crisis/.

[33] S. Shokrzadeh and E. Bibeau, 'Sustainable integration of intermittent renewable energy and electrified light-duty transportation through repurposing batteries of plug-in electric vehicles', Energy, vol. 106, pp. 701-711, 2016.
[34] A. Törkler, 'Electrodes and cells manufacturing white paper: Batteries Refurbishing \& Reuse', 2014.

[35] Nissan, 'XSTORAGE', 2017. [Online]. Available: https://www.nissan.co.uk/experience-nissan/electric-vehicleleadership/xstorage-by-nissan.html.

[36] BMW, 'Battery storage system electrified by BMW i announced at EVS29 in Montreal.', 2016. [Online]. Available: https://www.press.bmwgroup.com/usa/article/detail/T0261314EN_ US/battery-storage-system-electrified-by-bmw-i-announced-atevs29-in-montreal?language=en_US.

[37] N. M. P. Bocken, S. W. Short, P. Rana, and S. Evans, 'A value mapping tool for sustainable business modelling', Corp. Gov., vol. 13, no. 5, pp. 482-497, 2013.

[38] R. Amit and C. Zott, 'Creating Value Through Business Model Innovation', MIT Sloan Manag. Rev., vol. 53, no. 53310, pp. 4149, 2012.

[39] B. Klör, D. Beverungen, S. Bräuer, F. Plenter, and M. Monhof, ‘a Market for Trading Used Electric Vehicle Batteries - Theoretical Foundations and Information Systems', Ecis, no. 2015, pp. 1-18, 2015.

[40] P. Mock and Z. Yang, 'Driving Electrification: a global comparison of fiscal incentive policy for electric vehicles', ICCT The International Council on Clean Transportation, 2014. [Online]. Available: http://www.theicct.org/sites/default/files/publications/ICCT_EVfiscal-incentives_20140506.pdf.

[41] B. Nykvist and M. Nilsson, 'Rapidly falling costs of battery packs for electric vehicles', Nat. Clim. Chang., vol. 5, no. 4, pp. 329-332, 2015.

[42] M. Nilsson and B. Nykvist, 'Governing the electric vehicle transition - Near term interventions to support a green energy economy', Appl. Energy, vol. 179, pp. 1360-1371, 2016.

[43] M. O. Ramoni and H.-C. Zhang, 'End-of-life (EOL) issues and options for electric vehicle batteries', Clean Technol. Environ. Policy, vol. 15, no. 6, pp. 881-891, 2013.

[44] UL, 'The Afterlife of Electric Vehicle Batteries', 2017. [Online]. Available: http://www.ul.com/inside-ul/the-afterlife-of-electricvehicle-batteries/.

[45] Lux Research, 'Reuse or Recycle: The Billion-Dollar Battery Question', 2016. [Online]. Available: http://www.luxresearchinc.com/content/reuse-or-recycle-billiondollar-battery-question- 0 . 